\title{
Drawing out the Links
}

\section{Wird die Informationsgesellschaft tatsächlich „leicht und sauber" sein? Ein Über- blick über die internationale Literatur nährt hier eher Skepsis. Die Verbreitung von Informations- und Kommunikationstechnologien birgt sowohl große Risiken als auch große Chancen für ökologische Nachhaltigkeit. Dabei fallen insbesondere die indirekten und strukturellen Wirkungen ins Gewicht. Entscheidend ist, wie die Bilanz von Effizienzsteigerungen, Substitutionseffekten, neu generierter Nachfrage (rebound effect) sowie Lebensstilveränderungen ausfallen wird.}

$\mathrm{T}$ Von Julia Hertin und Frans Berkhout he relationship between the diffusion of information and communications technologies (ICTs) and the broader social goal of environmental sustainability is not well understood (1). Major efforts have been made to analyse the impacts of ICTs on the economy and on society: changes in work organisation and labour productivity, structural change in the economy, impacts on the processes of globalisation, a social 'digital divide' and so on (2).

However, little rigorous analysis of environmental impacts has been done. Partly this is because ICTs“ impacts on the environment appear to be relatively small compared to more traditional, resource intensive industries. But research is also limited by a lack of reliable data. Although some statistical sources exist, they naturally lag behind a fast changing reality. In this article we outline the main domains in which positive and negative impacts of ICTs on the environment are experienced.

\section{De- or Re-materialising?}

The current debate about digital technologies and the environment is characterised by a stark contrast between optimistic and pessimistic views. To some, environmental effects of ICTs appear to be exclusively positive because ,information“ is generally considered to be distinct from the material aspects of the economy. For example, Coyle has argued that the digital world is almost ,weightless" (3). If economic value is increasingly generated by intangible rather than tangible assets, then perhaps post-industrial economies are liberating themselves from the awkward imperatives of extracting, manipulating and disposing of natural resources. For others, however, ICTs enable and encourage unsustainable production and short-term consumerism.
Evidence to date suggests a more complex and uncertain relationship between information technologies and environmental sustainability. To bring some clarity to the claims that are made, it is useful to draw distinctions between

direct,

indirect and

- structural/ behavioural effects

of ICTs and e-commerce (see also table 1).

Table 1: ICT impacts on the environment

\begin{tabular}{|c|c|c|}
\hline & Positive impacts & Negative impacts \\
\hline Direct effects of ICT & $\begin{array}{l}\text { environmental monitoring } \\
\text { e.g. remote sensing }\end{array}$ & $\begin{array}{l}\text { environmental impacts of production, } \\
\text { use and disposal of ICTs } \\
\text { e.g. electronic waste }\end{array}$ \\
\hline Indirect effects of ICT & $\begin{array}{l}\text { improved efficiency, dematerialisation } \\
\text { and virtualisation } \\
\text { e.g. intelligent logistics, } \\
\text { electronic directories }\end{array}$ & $\begin{array}{l}\text { proliferation of electronic devices, } \\
\text { partial substitution } \\
\text { e.g. e-shopping as well as } \\
\text { private shopping trips }\end{array}$ \\
\hline $\begin{array}{l}\text { Structural and } \\
\text { behavioural effects of ICT }\end{array}$ & $\begin{array}{l}\text { structural and life style transitions } \\
\text { e.g. growth of 'light' industries, } \\
\text { green consumerism }\end{array}$ & $\begin{array}{l}\text { stimulating growth and re-materialisation } \\
\text { e.g. growth of long distance travel }\end{array}$ \\
\hline
\end{tabular}

\section{Direct Environmental effects}

Although important data gaps and fast changing technology do not allow a comprehensive assessment, it is widely recognised that the production, use and disposal of ICTs have become a serious environmental issue (4). In 1997, OECD countries produced ICT goods worth more than 720 billion US dollar, and the sector is still expanding.

Most ICT products (personal computers, network servers, mobile phones, cables, satellites, peripheral devices etc.) consist of a large number of different components the manufacture of which has a variety of environmental effects. The production of semiconductors, for example, causes significant emissions of acid fumes, volatile organic compounds, solvents, cleaning solutions, acids, and metals. Overall, the manufacture of ICT equipment causes a growing number of environmental problems, related to energy consumption, water discharges, air emissions and water and materials use (5). ICTs are produced through global supply chains. A typical personal computer contains 1500-2000 components sourced from around the world, and often transported by air. The aggregate environmental impacts of these complex supply chains are large, especially those related to transport.

Furthermore, ICT devices use a large amount of electricity. A typical medium-sized PC consumes about 150 Watt per hour. But residential energy use is also growing through the integration of ICTs into products and even commodities. These include advanced television equipment, mobile phones, handheld personal digital assistants and many other information appliances. For instance, set-top boxes are currently projected to add some $6.000 \mathrm{GWh}$ of power demand in the UK by 2010 (6). Electronic consumer goods account for 5-15 percent of residential energy use in industrialised societies.

According to Moore's Law, which has proven

Source: own compilation

relatively accurate, the performance of ICT doubles every 18 months. Rapid innovation cycles have led to a high turnover of hardware and software and to a fast increasing waste stream. In the EU in 1998, six million tons of electrical and electronic waste were generated. This corresponds to four per cent of total municipal waste, and is predicted to increase by at least three to five per cent per annum. The main area of concern for disposal is the metal content of electronic waste as well as a number of other materials such as flame-retardants and plastic softeners (7). At present, only a small proportion of ICT hardware is recycled. 


\section{- Indirect Effects: Efficiency Improvements ...}

The development, production and distribution of products and services involve complex processes in which information technologies play an increasingly important part. Although driven by the need to reduce costs, the optimisation of processes through ICTs has, by and large, benefited the environment. Preliminary evidence to support this argument at the macro-economic scale has been produced in a study into the impacts of the US Internet economy on global warming (8). Romm argued that in 1997 and 1998, the diffusion of ICTs improved aggregate energy productivity in the US economy by more than three percent, reversing a trend of slow declines in the previous decade.

ICTs enable the simulation of complex production systems in order to test and review costs, material use, and environmental emissions of design options. Once in operation, sensors and digital controls ensure efficient and flexible operation of more integrated facilities. Modern production systems can have tens of thousands of individual microprocessors embedded in them, performing a variety of tasks. Today up to 40 per cent of the value of a new manufacturing plant is accounted for by computercontrolled systems. But while these devices are critical for improving reliability, quality, safety and resource efficiency, improvements of this type have been achieved consistently in industry since computers were first introduced into manufacturing over 30 years ago. Efficiency savings enabled by ICTs are therefore not a new phenomenon.

Design software and simulation tools are recognised to reduce waste in production and operation and to generate more efficient products. Simple products such as packaging have, for instance, been radically de-materialised through the application of software-based design and environmen-

\section{Einen Überblick über alle bisher erschienenen Hefte des Informationsdienstes "Ökologisches Wirtschaften" finden Sie auf unseren Internetseiten unter der Adresse:}

\section{http://www.oekom.de}

tal appraisal. Many complex products such as cars contain microprocessor controls that improve the functionality of the product, but also control emissions. Information systems are also key to improving the efficiency of heating, cooling and lighting, a major use of electricity.

\section{... and Substitution Effects}

Substitutions of electronic information for materials and energy have also been proposed as leading to environmental benefits. Paper-based catalogues, encyclopaedias, newspapers and magazines have come under competitive pressure from cheaper and more easily retrieved and updated electronic sources of information. Similarly, downloading of music in digital format is perceived as a threat to the sales of music CDs. The use of digital cameras reduces the need for chemical processing which is associated with a range of negative environmental effects (9). Once again, a critical unanswered question is over how far these new technologies will stimulate a greater demand for new devices. Just as the use of computers did not lead to a paperless office, incomplete substitution of existing technologies by new digital systems could result in additional environmental burdens.

\section{- Transport and Distribution}

ICTs have been at the heart of the creation of more extensive markets, contributing to a rapid growth in global trade and so to the growth in demand for transport. But ICTs have also improved the efficiency of distribution (10), usually associated with environmental benefits. Some of these gains have been offset by demand for high speed and just-intime delivery by road, tending to reduce vehicle utilisation rates. Furthermore, e-business is likely to result in more geographically extended supply patterns, and therefore higher transport intensity for goods. The potential environmental effects of business-to-consumer e-commerce are similarly ambiguous. Complete replacement of car-based shopping trips by van-based delivery could reduce distance travelled - by 70 to 80 per cent according to one simulation (11). This level of substitution is highly unlikely.

\section{Beneficial Structural Change}

Many authors expect ICTs to facilitate a de-coupling of economic growth and environmental damage. In notions of the new economy the use of information technology is mainly concerned with the manipulation of ideas, rather than energy and materials. About 35 per cent of US economic growth between 1995 and 1998 has been attributed to the IT business, leading in turn to the suggestion that a transformation in the material basis of economies is underway. Information technologies contribute to a long-standing structural change in the economy away from materials intensive activity and towards more service-based activities. However, service sectors themselves are supported by material infrastructures and transactions, and are not as light as is often assumed (12). While the rapid diffusion of ICTs contributes to incremental improvements in relative resource efficiency, there is empirical evidence that in absolute terms these economies are still ,materialising“, especially when the environmental burdens associated with traded goods are included (13).

\section{The Rebound Effect}

The rebound effect, familiar from the transport and energy sectors, occurs when efficiency gains stimulate new demands. This could occur through two mechanisms. First, induced productivity improvements will tend to lead to falling prices of raw materials and energy, and rates of improvement in resource efficiency would be expected to slow. The producers of these materials will undertake efforts to innovate new products, and new markets for environmentally damaging materials may develop.

A second mechanism is the generation of new capacity. Many ICT applications allow a better management of time, money, labour and infrastructure, thus providing scope for new demand. The Internet provides greater choices and reduces transaction costs, thereby enabling people to consume more. Whether this new demand will offset dematerialisation effects depends largely on the collective choices of consumers. Will the money and time freed through the use of ICTs be spent in the consumption of environmentally damaging goods and services, or on ,immaterial“ services? Anecdotal evidence suggests that the rebound effect is a real threat to incremental efficiency gains. Some US teleworking studies have found that initial reductions in car travel are partially offset by stimulation of new driving (14). This includes living further away from the workplace, or making short trips from home during more fragmented work days.

\section{Life Style and Behavioural Changes}

Finally, new information technologies are likely to have broader impact on social values, life styles and culture. These changes and their impact on the en- 
vironment remain largely unknown. One possible trend is the emergence of a new green consumerism based on the new possibilities of information technologies. ICT systems may allow consumers and civil society to translate values into purchasing and other decisions more easily. For example, online information services could provide consumers with more information about the ethical performance of competing products. Enabled to make informed choices about products on the basis of environmental criteria, consumers could stimulate more environmentally responsible production and innovation. On the other hand, the fact that ICT networks decrease the importance of geographical distance could also lead to a re-mobilisation, not only of goods, but also of labour and leisure. The greater connectivity between people provided by e-mail and the internet, is likely to stimulate the desire to travel.

\section{- Conclusions}

This brief overview suggests that the diffusion of ICTs holds large risks as well as great potentials for environmental sustainability. Although pollution related to the production, use and disposal of ICT hardware is a serious environmental issue, we would argue that direct effects are small compared to indirect and structural impacts. These are critical in determining whether digital technologies help de-materialising post-industrial societies or whether they enable a faster and more damaging exploitation of the natural environment.

Claims that the information society will be ,weightless" or ,lean and clean" have to be regarded with scepticism. The virtual economy is deeply embedded in the real, material economy, just as it is embedded in the real, political world (15). The net effect of changes promoted by the diffusion of ICTs will depend on the balance between dematerialising effects, and the counter re-materialising influences of economic growth and the physical investments that are made to motivate the information economy. This balance will not only be a result of the choices of individuals, but also depend on framework conditions created by collective decisions in a range of policy areas such as environment, transport, energy, and trade.

\section{References}

(1) This article draws on Berkout, F./ Hertin, J.: De-materialising and re-materialising: Digital technologies and the environment (paper submitted to Futures) and Eames M./ Berkhout F./ Hertin, J./ Hawkins R./ Mackerron G.:

E-topia? Scenarios for e-commerce and sustainability. In: Wils- don, J. (ed): Digital Futures: living in a dot-com world, London 2001.

(2) Castells, M.: The Information Age: Economy, Society and Culture, Cambridge MA 1996.

(3) Coyle, D.: The Weightless World: Strategies for Managing the Digital Economy, Boston 1998.

(4) Kelly, H.: Information Technology and the Environment: Choices and Opportunities. In: iMP: The Magazine on Information Impacts, October 1999 (www.cisp.org/imp/).

(5) Matthews, H.S.: The Environmental Implications of the Growth of the Information and Communications Technology Sector. Paper for Environment Directorate, OECD, Paris 2001; Hilty, L.M./ Ruddy, T.F.: Towards a sustainable information society. In: Informatik - Informatique №. 4/2000, pp. 2-9.

(6) Projection by the UK Market Transformation Programme (www.mtprog.com).

(7) van Drunen, M./ Olsthoorn, A.A.: Environmental impacts of the computer industry, IVM-VU, Working Paper W99/06, Amsterdam 1999.

(8) Romm, J.: The Internet Economy and Global Warming. Center for Energy and Climate Solutions, Washington 1999.

(9) Cohen, N.: Greening the Internet: Ten ways e-commerce could affect the environment and what we can do. In: iMP: The Magazine on Information Impacts, October 1999 (www.cisp. org/imp/)

(10) Hopkinson, P./ James, P.: Virtual traffic - will e-commerce mean less transport and more sustainable logistics? Report for Digital Futures project, University of Bradford and UKCEED, November 2000. See also Picot, A.: Bits statt Atome? In: Ökologisches Wirtschaften, No. 1/2000, pp. 14-15.

(11) Cairns, S.: Home Delivery of Electronic Shopping: The environmental consequences. ESRC Transport Studies Unit, University College, London 1999.

(12) Leadbeater, C.: Mind over matter: greening the new economy. Green Alliance, London 2000.

(13) Matthews, E.: The Weight of Nations: Material oufflows from industrial economies. World Resources Institute, Washington DC 2000 .

(14) Hopkinson, P./ James, P./ Selwyn, J.: The Environmental and Social Impact of Teleworking. Paper presented to the 6th European Conference on Telework and New Ways of Working, Aarhus/ Denmark 1999.

(15) Sassen, S.: Digital Networks and the State: Some Governance Questions. In: Theory, Culture and Society, Vol. 17 (2000), №. 4, pp. 19-33.

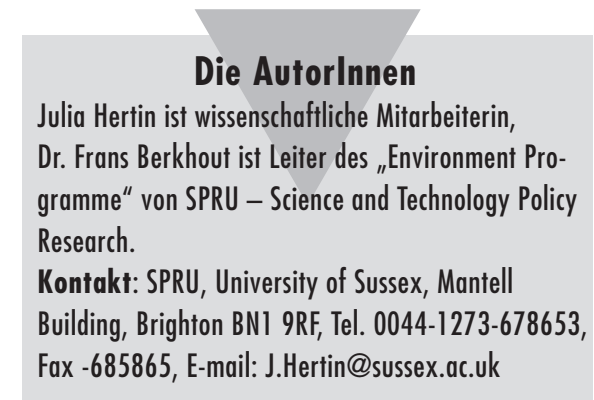

\section{politische ökologie ${ }^{76}$}

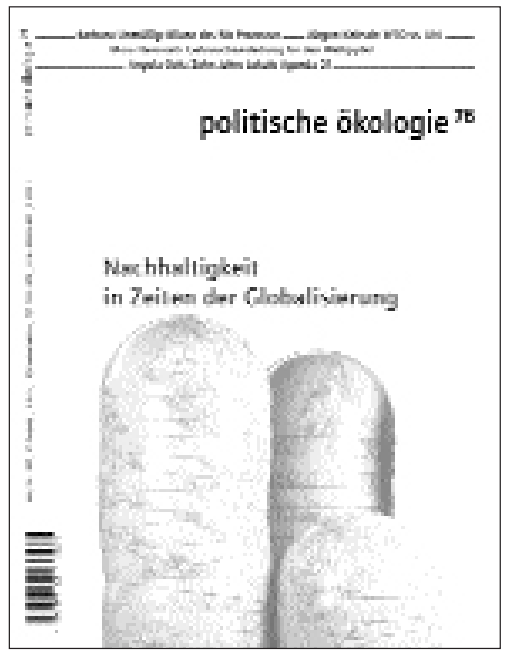

\section{Nachhaltigkeit in Zeiten der Globalisierung}

Armut, Klimawandel, Terrorismus, Wirtschaftskrisen - in der globalisierten Welt hängt alles mit allem zusammen. Im Kern geht es dabei um die Frage der Gerechtigkeit: Gerechtigkeit zwischen den Generationen, zwischen Nord und Süd, zwischen arm und reich.

Kann hier das Konzept der Nachhaltigkeit Lösungen anbieten, die seit den Terroranschlägen vom 11. September 2001 umso dringlicher gesucht werden? Und welchen Stellenwert nimmt Ökologie in der Debatte um Nachhaltige Entwicklung ein?

Im Licht der eher ernüchternden Bilanz seit dem historischen Rio-Gipfel von 1992 will der kommende Weltgipfel in Johannesburg 2002 Strategien für die Zukunft entwickeln. Vorbereitungstreffen jagen einander, in der Flut von Veröffentlichungen über den Rio-Folgeprozess verlieren selbst Spezialistinnen und Spezialisten den Überblick. Die politische ökologie 76 sortiert vor, analysiert die Entwicklungen seit Rio und fragt nach den Hemmnissen einer weltweiten sozialen und ökologischen Erneuerung. Sie bietet Orientierungshilfen und Informationen, die weit über den Gipfel hinaus Relevanz haben.

\section{www.oekom.de}

Für 10,00 Euro erhältlich bei pan adress

Semmelweisstraße 8, D-82152 Planegg

Fon $++49 /(0) 89 / 857$ 09-155

Fax ++49/(0)89/857 09-131

E-Mail kontakt@oekom.de 
(c) 20I0 Authors; licensee IÖW and oekom verlag. This is an article distributed under the terms of the Creative Commons Attribution Non-Commercial No Derivates License (http://creativecommons.org/licenses/by-nc-nd/3.o/), which permits unrestricted use, distribution, and reproduction in any medium, provided the original work is properly cited. 